\title{
Modulation by Estrogen-Receptor Directed Drugs of 5-Hydroxytryptamine-2A Receptors in Rat Brain
}

\author{
Michel Cyr, B.Sc., Michelle Landry, M.Sc. and Thérèse Di Paolo, Ph.D.
}

Hormonal specificity of modulation of brain $5-\mathrm{HT}_{2 \mathrm{~A}}$ receptors was investigated by comparing activity of compounds with varying effects on estrogen response in breast, bone, and uterus. A two-week estradiol treatment stimulated the decreased uterine weight of ovariectomized rats to intact rat values whereas an increase of $29 \%$ with tamoxifen and $16 \%$ with raloxifene was observed compared to vehicle-treated ovariectomized rats. In 18 assayed brain regions, ovariectomy decreased $5-H T_{2 A}$ receptor binding and $m R N A$ levels in anterior cingulate and frontal cortices, striatum, and nucleus accumbens; estradiol restored this decrease to intact rat values. Dehydroepiandrosterone (DHEA) increased ovariectomized rats $5-\mathrm{HT}_{2 A}$ receptor expression only in striatum and cortical amygdala. Tamoxifen increased $5-\mathrm{HT}_{2 \mathrm{~A}}$ receptor density only in striatum. Raloxifene, an uterine estrogen receptor (ER) antagonist, increased, like estradiol, $5-\mathrm{HT}_{2 A}$ receptor density and expression in cingulate and frontal cortices, striatum, and nucleus accumbens. Brain regional specificity of estradiol, DHEA, tamoxifen, and raloxifene on $5-\mathrm{HT}_{2 A}$ receptors was observed which can be dissociated from peripheral activity.

[Neuropsychopharmacology 23:69-78, 2000] (C) 2000 American College of Neuropsychopharmacology. Published by Elsevier Science Inc. All rights reserved
KEY WORDS: Ovariectomy; Raloxifene; Tamoxifen;

Estradiol; DHEA; 5- $\mathrm{HT}_{2 \mathrm{~A}}$ receptor

5-Hydroxytryptamine (5-HT) is a neurotransmitter that plays a major role in cognition, mood, and behavior (Zifa and Fillion 1992). The efficacy of 5-HT uptake inhibitors in the treatment of depression has suggested that major depression is due mainly to a disorder of central 5-HT transmission (Charney 1998). Furthermore, the therapeutic success of clozapine and, more recently, risperidone has focused attention on the 5-HT system and its interaction with the dopaminergic sys-

From the Oncology and Molecular Endocrinology Research Center and Faculté de Pharmacie, Université Laval, Sainte-Foy, Québec, Canada.

Address correspondence to: Dr. Thérèse Di Paolo, Oncology and Molecular Endocrinology Research Center, Laval University Medical Center (CHUL), 2705, Laurier Boulevard, Sainte-Foy, Quebec, Canada G1V 4G2.

Received August 20, 1999; revised December 20, 1999; accepted December 27, 1999. tem as an avenue for improved treatment of psychotic illnesses (Lieberman et al. 1998). It is suggested, moreover, that an abnormality in the 5-HT system is second only to the dopamine hypothesis as a potential neurochemical factor involved in schizophrenia (Lieberman et al. 1998). On the other hand, animal studies have clearly documented an action of estradiol on neurotransmitters such as dopamine (Di Paolo 1994) and 5-HT (Bethea et al. 1998), and similar effects are likely to occur in humans.

We have recently shown that sex steroid withdrawal following ovariectomy of rats decreases 5-hydroxytryptamine-2A $\left(5-\mathrm{HT}_{2 \mathrm{~A}}\right)$ receptor density in the dorsal raphe, striatum, nucleus accumbens, and frontal cortex (Cyr et al. 1998). Estradiol treatment of ovariectomized rats increases and restores to intact values the $5-\mathrm{HT}_{2 \mathrm{~A}}$ receptor density in these regions. In the frontal cortex, changes in $5-\mathrm{HT}_{2 \mathrm{~A}}$ receptor $\mathrm{mRNA}$ levels are parallel to those of the receptor density after ovariectomy and estradiol treatment (Cyr et al. 1998). It is known that interaction of the estrogen receptor (ER)/ligand complex 
with the promoter estrogen response element regulates estrogen-sensitive gene transcription (Paige et al. 1999). On the other hand, with newly designed ligands, specific conformation of the receptor-ligand complex will activate unique subsets of estrogen-responsive genes resulting in differential modulation and, ultimately, gene- and tissue-selective outcomes (Paige et al. 1999). Interestingly, we have recently shown that estrogen regulates N-methyl-D-aspartate (NMDA) receptors with tissue selectivity; an increase has been observed in the hippocampus after estradiol treatment, whereas, a decrease was found in the frontal cortex (Cyr et al. 2000), two rat brain areas expressing ER $\beta$ (Laflamme et al. 1998).

Activity in the rat brain of ER ligands which have shown tissue-specific estrogen agonist and/or antagonist effects in peripheral tissues has not been reported on $5-\mathrm{HT}_{2 \mathrm{~A}}$ receptor density or expression. Hence, we have investigated the effect of ovariectomy and replacement therapy with vehicle, $17 \beta$-estradiol, tamoxifen, and raloxifene on 5- $\mathrm{HT}_{2 \mathrm{~A}}$ receptor density and on uterine stimulation. Tamoxifen is a first generation of selective estrogen receptor modulators (SERMs) and raloxifene is a second generation of such compounds (Grese and Dodge 1998). In a second experiment, where the animals were perfused, we investigated the effect of ovariectomy and replacement therapy with vehicle, $17 \beta$-estradiol, DHEA, tamoxifen, and raloxifene on $5-\mathrm{HT}_{2 \mathrm{~A}}$ receptor mRNA levels. The present study investigated the specificity of the hormonal modulation of $5-\mathrm{HT}_{2 \mathrm{~A}}$ receptors, this knowledge being potentially important for a better understanding of ERs and serotonin receptor interaction.

\section{MATERIALS AND METHODS}

\section{Animals}

Adult female Sprague-Dawley rats weighing approximately $250 \mathrm{~g}$ were purchased from Charles River Canada, Inc. (St-Constant, Québec, Canada). The animals were housed two per cage in a light (12 h light/day; lights on at 8:30 A.M.) and temperature $\left(22-23^{\circ} \mathrm{C}\right)$ controlled environment. The animals received rat chow and water ad libitum. The animal studies were all approved by the Laval University Animal Care Committee. All efforts were made to minimize animal suffering and to reduce the number of rats used.

\section{Treatments}

The first experiment consisted of rats divided into five groups of ten animals each. The first group comprised intact control rats at random stages of the estrous cycle treated with vehicle. The four other groups were rats ovariectomized for two weeks and treated with either vehicle; $80 \mu \mathrm{g} / \mathrm{kg}$ 17 $\beta$-estradiol (Sigma, St-Louis, MO); $1 \mathrm{mg} / \mathrm{kg}$ tamoxifen citrate (Sigma); or $1 \mathrm{mg} / \mathrm{kg}$ raloxifene (gift of F. Labrie, Oncology and Molecular Endocrinology Research Center, Québec, Canada). Raloxifene was synthesized in the laboratory of Dr. F. Labrie; purity $(99.10 \%)$ and identity were assessed by high performance liquid chromatography (HPLC), ${ }^{1} \mathrm{H}$ and ${ }^{13} \mathrm{C}$ nuclear magnetic resonance (NMR), and Fourier transform infrared (FTIR) spectroscopy. Rats were ovariectomized under anesthesia with an $1.5 \%$ halothane air mixture. The drug doses were chosen for maximal occupancy of the ERs (Martel et al. 1998). Treatment began the day after ovariectomy once daily for 14 days; $0.5 \mathrm{ml}$ per rat was injected subcutaneously as suspension (vehicle) in $4 \%$ ethanol, $4 \%$ polyethylene glycol 600 (PEG-600), $1 \%$ gelatin, and $0.9 \% \mathrm{NaCl}$. The uteri were immediately removed at sacrifice, freed from connective and adipose tissue, and weighed.

The second experiment consisted of six groups of four rats each. One group comprised intact control rats at random stages of the estrous cycle treated with vehicle $(0.4 \%$ methylcellulose); five groups of rats were ovariectomized for two weeks and treated with either vehicle, one silastic implant of 17ß-estradiol (17 $\beta$-estradiol:cholesterol 1:50, $\mathrm{w} / \mathrm{w}), 120 \mathrm{mg} / \mathrm{kg}$ DHEA (Sigma), $1 \mathrm{mg} / \mathrm{kg}$ tamoxifen citrate, or $1 \mathrm{mg} / \mathrm{kg}$ raloxifene. Rats were ovariectomized under anesthesia with $1.5 \%$ halothane air mixture. Treatment began the day after ovariectomy once daily for 14 days; $0.5 \mathrm{ml}$ per rat was injected subcutaneously as suspension in $0.4 \%$ methylcellulose except for DHEA applied topically on the skin once daily as a solution in $50 \%$ ethanol-50\% propylene glycol $(0.5 \mathrm{ml} /$ application/rat $)$ (Labrie et al. 1996).

\section{Brain Slices Preparation}

Animals of the first protocol were killed by decapitation and their brains were rapidly removed, flash-frozen in isopentane over dry ice, individually wrapped in aluminum foil, and kept at $-80^{\circ} \mathrm{C}$. Brains were then immersed in Tissue-Tek (Miles, Inc., Elkhart, USA) at $-20^{\circ} \mathrm{C}$, mounted on cryostat chucks, and cut into 20 $\mu \mathrm{m}$-thick coronal slices. Adjacent coronal slices were cut from the anterior region of cingulate and frontal cortices (Bregma 4.2 to $3.7 \mathrm{~mm}, n=40$ slices), posterior region of cingulate and frontal cortices, striatum and nucleus accumbens (Bregma 1.6 to $1.2 \mathrm{~mm}, n=40$ slices) according to the atlas of Paxinos and Watson (1998). Slices were thaw-mounted on superfrost precleaned slides (Trade Mark; Fisher, Nepean, ON, Canada) and vacuum-desiccated at $4^{\circ} \mathrm{C}$ for 12 hours before storing at $-80^{\circ} \mathrm{C}$.

Animals of the second experiment were deeply anesthetized via an intraperitoneal (i.p.) injection of $0.5 \mathrm{ml}$ 
of a mixture of ketamine hydrochloride $(80 \mathrm{mg} / \mathrm{kg})$ and xylazine $(10 \mathrm{mg} / \mathrm{kg})$. Subsequently, the rats were rapidly perfused transcardially with $0.9 \%$ saline, followed by $4 \%$ paraformaldehyde in $0.1 \mathrm{M}$ borax buffer $(\mathrm{pH} 9.5$ at $4^{\circ} \mathrm{C}$ ). Brains were removed from the skull, postfixed for 1-3 days, and then placed in $10 \%$ sucrose and $4 \%$ paraformaldehyde-borax buffer $(\mathrm{pH} 9.3)$ overnight at $4^{\circ} \mathrm{C}$. The frozen brains were mounted on a microtome (Reichert-Jung; Cambridge Instruments Company, Deerfield, IL) and cut into $30 \mu \mathrm{m}$-thick coronal sections. The slices were collected in a cold cryoprotectant solution $(0.05 \mathrm{M}$ sodium phosphate buffer, $30 \%$ ethylene glycol, $20 \%$ glycerol) and stored at $-20^{\circ} \mathrm{C}$.

\section{5-HT ${ }_{2 \mathrm{~A}}$ Receptor Binding Autoradiography}

Autoradiography of 5- $\mathrm{HT}_{2 \mathrm{~A}}$ receptor binding sites with $\left[{ }^{3} \mathrm{H}\right]$ ketanserin $(2 \mathrm{mM}, 66.4 \mathrm{Ci} / \mathrm{mmol}$, Amersham) was performed as previously described (Cyr et al. 1998). Sections and calibrated standards (Microscales, Amersham) were exposed for 35 days to Amersham Hyperfilm ${ }^{3} \mathrm{H}$. The autoradiograms were analyzed using the software package NIH Image 1.63 on a PowerMacintosh 7100 assisted videodensitometry (Sony camera XC-77), which provides values of receptor densities expressed in $\mathrm{fmol} / \mathrm{mg}$ of tissue. For all densitometric measurements, the optical density of the total area of the brain structures was measured. For each brain structure, the mean of the total binding from eight coronal sections and the non-specific binding from eight other adjacent coronal sections for each animal was measured. The left and right brain hemispheres were quantified and gave essentially the same results, therefore this data was pooled.

\section{5-HT $2 \mathrm{~A}$ Receptor In Situ Hybridization Histochemistry}

The complementary sequence encoding the rat $5-\mathrm{HT}_{2 \mathrm{~A}}$ receptor (Pritchett et al. 1988) was subcloned in pSP64/65 vector at Eco RI/Sal I site. $\left[{ }^{35} \mathrm{~S}\right] \mathrm{UTP}$-labeled antisense cRNA probes were produced in vitro by transcription of linearized pSP64 plasmid (digested with Eco RI) using SP6 RNA polymerase (Promega, Madison, WI). All the following steps were carried out in diethylpyrocarbonate treated water. Brain sections were desiccated under vacuum overnight and fixed in $4 \%$ paraformaldehyde in phosphate buffer $(0.1 \mathrm{M}, \mathrm{pH} 7.2)$ for $20 \mathrm{~min}$. Slides were deproteinated in a proteinase solution $(10 \mu \mathrm{g} /$ $\mathrm{ml}$ proteinase $\mathrm{K}$ in $0.1 \mathrm{M}$ Tris, $\mathrm{pH} 7.5$, and $50 \mathrm{mM}$ ethylenediaminetetraacetic acid (EDTA) $\mathrm{pH} \mathrm{8.0)} \mathrm{for} 25 \mathrm{~min}$ at $37^{\circ} \mathrm{C}$ and treated with triethanolamine $(0.1 \mathrm{M}, \mathrm{pH}$ 8.0) containing $0.25 \%(\mathrm{v} / \mathrm{v})$ acetic anhydride for $10 \mathrm{~min}$. Slides were then ethanol dehydrated and vacuum dried 4 hours before in situ hybridization histochemistry.
The in situ hybridization histochemistry and the posthybridization washes were performed as previously described (Cyr et al. 1998). To generate autoradiograms, sections were exposed to Kodak BioMax MR film for two days. Quantification of autoradiograms was carried out by densitometry image analysis using a transmission density scale (Stouffer Graphic Arts Equipments Company, Inc., South Bend, USA) and the software package NIH Image 1.63 on a PowerMacintosh 7100 assisted videodensitometry (Sony camera XC-77).

\section{Statistical Analysis}

Experimental data was compared using analysis of variance (ANOVA) with the software Statviews 4.51 for MacIntosh Computer, followed by post-hoc pairwise comparisons with a Fisher's probability of least significant difference test (PLSD). Statistical comparisons of $\log$ of uterine weights was used.

\section{RESULTS}

\section{Expression of 5-HT $2 \mathrm{~A}$ Receptor}

High to very high hybridization signal was found in the cerebral cortex. A decreasing gradient was observed from the prefrontal cortex to the frontoparietal cortex. Hence, the cingulate and frontal cortex showed very high level of $5-\mathrm{HT}_{2 \mathrm{~A}}$ receptor transcripts but the rest of the neocortex was also enriched. The signal presented a laminar distribution in four bands, corresponding to layers 2,4 , and the deep regions of layers 5 and 6 , close to the corpus callosum. High hybridization signal was found in the cortical nucleus of the amygdala, piriform and enthorinal cortex, claustrum, olfactory tract, habenula, CA3 hippocampal subregion, endopiriform nucleus, medial mammillary nucleus of the hypothalamus and some nucleus of the brainstem and spinal cord such as motor cranial nerve nuclei, red nucleus, and pontine nuclei. A low to moderate hybridization signal was detected in the striatum, nucleus accumbens, substantia nigra pars compacta, CA1-3 stratum oriens and some nuclei of the thalamus such as the reticular nucleus, the lateral geniculate nucleus, the zona incerta, as well as the anterodorsal and ventromedial nucleus (Figure 1).

\section{Uterine Stimulation}

Ovariectomy at two weeks in rats led to a $62 \%$ decrease in uterine weight compared to intact rats (Figure 2). Estradiol treatment stimulated uterine weights to intact values whereas tamoxifen increased uterine weights by $29 \%$ and raloxifene by $16 \%$ compared to ovariectomized rats (Figure 2). 

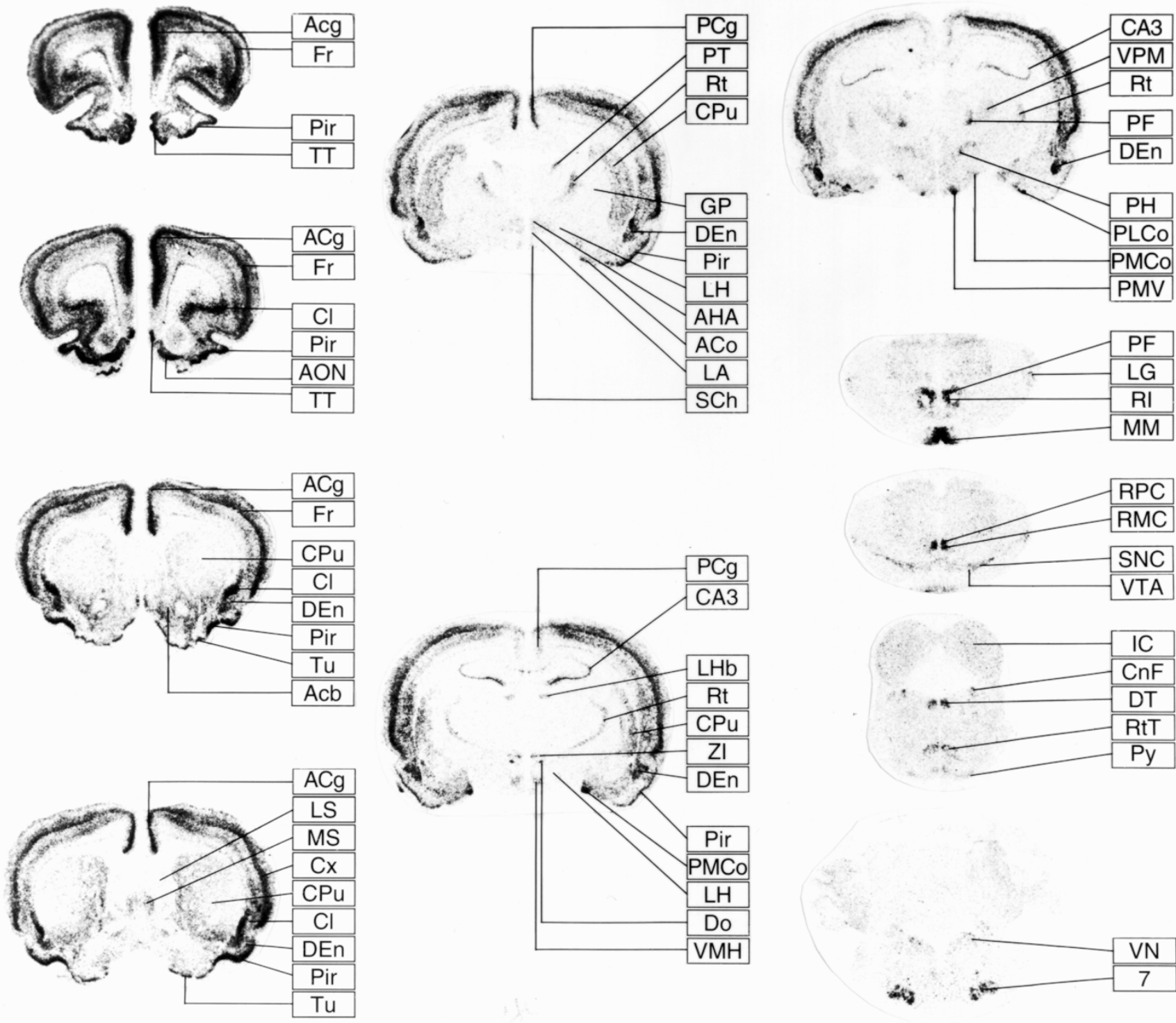

Figure 1. Distribution of mRNA encoding the 5- $\mathrm{HT}_{2 \mathrm{~A}}$ receptor throughout the brain of an intact female rat. Thirty $\mu \mathrm{m}$ coronal sections of the same animal hybridized with specific rat cRNA probe are shown. 7: Facial nucleus; Acb: Nucleus accumbens; Acg: Anterior cingulate cortex; Aco: Anterior cortical amygdaloid nucleus; AHA: Anterior hypothalamic area; AON: Anterior olfactory nucleus; CA3: Fields CA3 of Ammon's horn; Cl: Claustrum; CnF: Cuneiform nucleus; Cpu: Caudate putamen (Striatum); Cx: Cerebral cortex; DEn: Dorsal endopiriform nucleus; Do: Dorsal hypothalamic nucleus; DT: Dorsal tegmental nucleus; Fr: Frontal cortex; GP: Globus pallidus; IC: Inferior colliculus; LA: Lateroanterior hypothalamic nucleus; LG: Lateral geniculate nucleus; LH: Lateral hypothalamic area; LHb: Lateral habenular nucleus; LS: Lateral septal nucleus; MM: Medial mammillary nucleus; MS: Medial septal nucleus; Pcg: Posterior cingulate cortex; PF: Parafascicular thalamic nucleus; PH: Posterior hypothalamic area; Pir: Piriform cortex; PLCo: Posterolateral cortical amygdaloid nucleus; PMCo: Posteromedial cortical amygdaloid nucleus; PMV: Premammillary nucleus, ventral region; PT: Paratenial thalamic nucleus; Py: Pyramidal tract; RI: Rostral interstitial nucleus of the medial longitudinal fasciculus; RMC: Red nucleus, magnocellular region; RPC: Red nucleus, parvocellular region; Rt: Reticular thalamic nucleus; RtT: Reticulotegmental nucleus of the pons; Sch: Suprachiasmatic nucleus; SNC: Substantia nigra, pars compacta; TT: Tenia tecta; Tu: Olfactory tubercle; VN: Vestibular nucleus; VMH: Ventromedial hypothalamic nucleus; VPM: Ventral posteromedial thalamic nucleus; VTA: Ventral tegmental area; ZI: Zona incerta.

\section{Effect of Ovariectomy and Various Treatments on 5-HT ${ }_{2 \mathrm{~A}}$ Receptors}

The effect of hormonal modulations was studied in eighteen brain regions chosen based upon their impor- tance in mental diseases such as schizophrenia and depression, their high density of $5-\mathrm{HT}_{2 \mathrm{~A}}$ receptors and/or ERs. No effect of ovariectomy and treatment of ovariectomized rats with estradiol, DHEA, tamoxifen, or ralox- 
Uterine stimulation

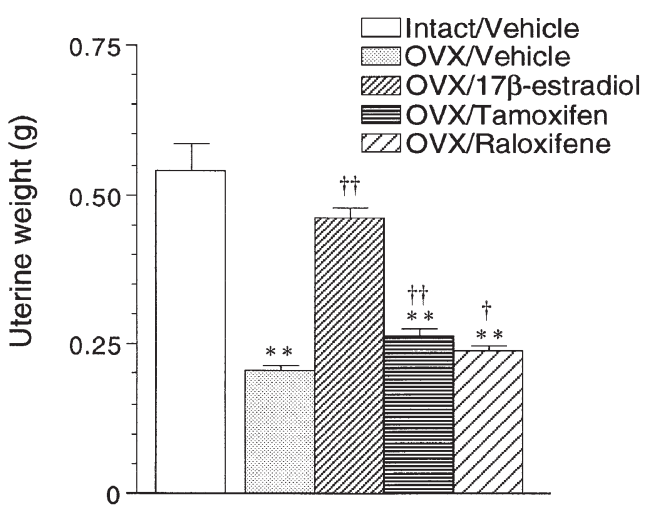

Figure 2. Uterine weight of intact rats from the first experiment as well as ovariectomized rats (two weeks) receiving vehicle (once daily, s.c.) or a two-week replacement therapy with $17 \beta$-estradiol $(20 \mu \mathrm{g})$, tamoxifen $(250 \mu \mathrm{g})$, or raloxifene $(250 \mu \mathrm{g})$. Results are expressed in gram \pm S.E.M. of ten rats. ${ }^{* *} p<.01$ vs. Intact/Vehicle; ${ }^{\dagger} p<.05$ and ${ }^{++} p<.01$ vs. OVX/Vehicle.

ifene was measured in the CA3 hippocampal subregion, claustrum, dorsomedial hypothalamic nucleus, endopiriform cortex, parietal cortex, lateral habenular nucleus, olfactory tubercle, piriform cortex, reticulate nucleus, ventromedial hypothalamus, and zona incerta (data not shown). The following results focus on brain regions where significant $5-\mathrm{HT}_{2 \mathrm{~A}}$ receptor changes were observed. The ovariectomy and steroid treatments gave similar results in layers 2, 4, and the deep regions of layers 5 and 6 of the cingulate, and frontal and fronto- parietal cortices. Thus, the total area of these brain structures were measured. Results for the anterior cingulate cortex included the prelimbic cortex and area 1 of the cingulate cortex, whereas the anterior frontal cortex included the primary and secondary motor cortices according to Paxinos and Watson (1998). No effect of ovariectomy and treatments were observed in the posterior regions of cingulate and frontal cortices.

\section{Ovariectomy}

Ovarian hormone withdrawal two weeks after ovariectomy led to a decrease of $5-\mathrm{HT}_{2 \mathrm{~A}}$ receptor specific binding and mRNA levels, respectively, by $30 \%$ and $29 \%$ in the anterior cingulate cortex, and by $29 \%$ and $22 \%$ in the anterior frontal cortex compared to intact rat values (Figures 3 and 4). Ovariectomy also decreased 5- $\mathrm{HT}_{2 \mathrm{~A}}$ receptor specific binding by $33 \%$ in the striatum and $30 \%$ in the nucleus accumbens (Figure 3), whereas a tendency to decrease of $22 \%$ in striatum and $28 \%$ in nucleus accumbens was measured for the mRNA levels of this receptor (Figure 4). Moreover, ovariectomy in rats from the second experiment decreased $5-\mathrm{HT}_{2 \mathrm{~A}}$ receptor mRNA levels by $26 \%$ in the cortical nucleus of the amygdala (Figure 4).

\section{Treatment with Estradiol}

Estradiol treatment of ovariectomized rats significantly restored $5-\mathrm{HT}_{2 \mathrm{~A}}$ receptor specific binding and mRNA levels to intact rat values in the anterior cingulate and anterior frontal cortices, striatum, and nucleus accum-

\section{$5-\mathrm{HT}_{2 \mathrm{~A}}$ receptor autoradiography}

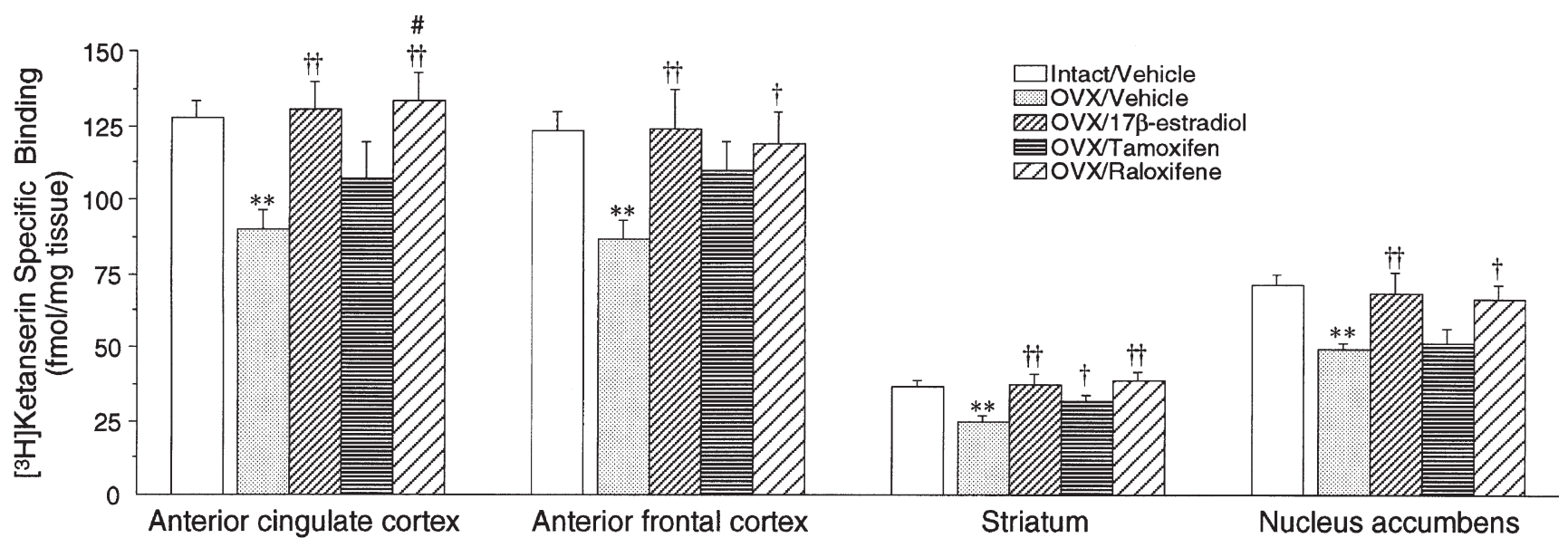

Figure 3. $\left[{ }^{3} \mathrm{H}\right]$ Ketanserin $(2 \mathrm{nM})$ specific binding to $5-\mathrm{HT}_{2 \mathrm{~A}}$ receptors in the anterior cingulate and frontal cortices, striatum and nucleus accumbens of intact rats as well as ovariectomized rats (two weeks) receiving vehicle (once daily, s.c.) or a twoweek replacement therapy of with $17 \beta$-estradiol $(20 \mu \mathrm{g})$, tamoxifen $(250 \mu \mathrm{g})$, or raloxifene $(250 \mu \mathrm{g})$. Results are expressed in $\mathrm{fmol} / \mathrm{mg}$ of tissue \pm S.E.M. of six rats. ${ }^{* *} p<.01$ vs. Intact/Vehicle; ${ }^{\dagger} p<.05$ and ${ }^{+\dagger} p<.01$ vs. OVX/Vehicle; \# $p<.05$ vs. OVX/Tamoxifen. 


\section{In situ Hybridization of the $5-\mathrm{HT}_{2 \mathrm{~A}}$ receptor Estradiol treatment}

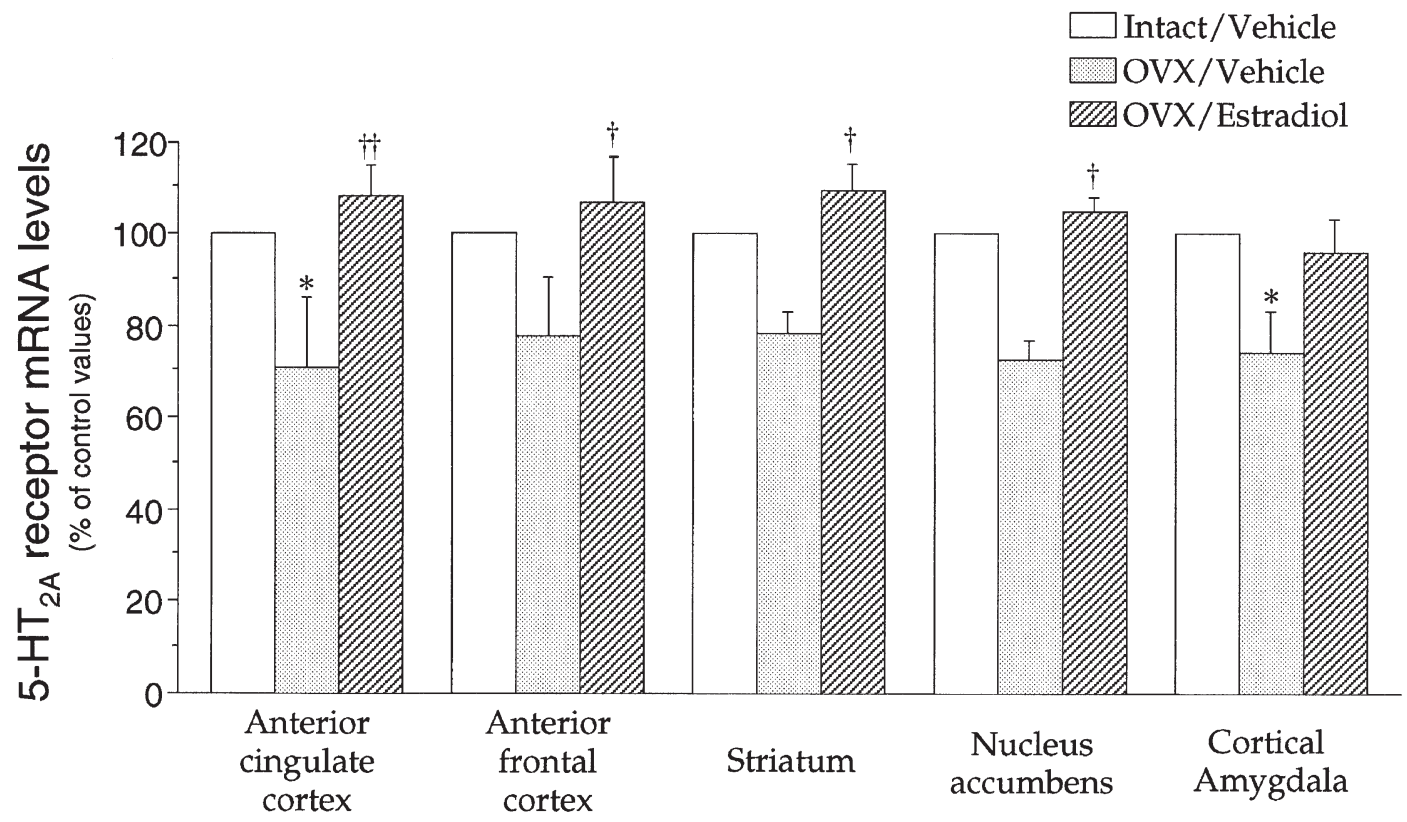

Figure 4. In situ hybridization of $5-\mathrm{HT}_{2 \mathrm{~A}}$ receptors in the brain of intact rats receiving vehicle (once daily, s.c., two weeks) as well as ovariectomized rats (two weeks) receiving vehicle (once daily, s.c.) or a replacement therapy with $17 \beta-e s t r a d i o l$ ( $E_{2}$, one silastic implant). Results are expressed as percent of control values \pm S.E.M. of four rats. Control values (Intact/Vehicle) in relative optical density were 0.247 in anterior cingulate cortex, 0.212 in anterior frontal cortex, 0.072 in striatum, 0.120 in nucleus accumbens, and 0.309 in the cortical nucleus of the amygdala. ${ }^{*} p<.05$ vs. Intact/Vehicle; ${ }^{\dagger} p<.05$ and ${ }^{++} p<.01$ vs. OVX/Vehicle.

bens (Figures 3 and 4). A tendency to increase by $22 \%$ in the cortical nucleus of the amygdala was measured for $5-\mathrm{HT}_{2 \mathrm{~A}}$ receptor mRNA expression after the estradiol treatment (Figure 4).

\section{Treatment with DHEA}

DHEA treatment significantly increased $5-\mathrm{HT}_{2 \mathrm{~A}}$ receptor mRNA levels by $31 \%$ in the striatum and the cortical nucleus of the amygdala, whereas a tendency to increase was observed in the cingulate and frontal cortices as well as the nucleus accumbens (Figure 5).

\section{Treatments with SERMs}

Tamoxifen treatment of ovariectomized rats increased $5-\mathrm{HT}_{2 \mathrm{~A}}$ receptor specific binding in the striatum, whereas this was non-significant in the cingulate and frontal cortices as well as the nucleus accumbens (Figure 3). This treatment had a tendency to increase $5-\mathrm{HT}_{2 \mathrm{~A}}$ receptor mRNA levels in the cingulate and frontal cortices. In the striatum, a marked difference in mRNA levels of $5-\mathrm{HT}_{2 \mathrm{~A}}$ receptors $(p<.05)$ for rats treated with tamox- ifen compared to raloxifene was observed (Figure 6). Raloxifene treatment, on the other hand, restored to intact rat values $5-\mathrm{HT}_{2 \mathrm{~A}}$ receptor specific binding and mRNA levels, similar to estradiol, in the anterior cingulate and anterior frontal cortices, as well as striatum and nucleus accumbens of ovariectomized rats (Figures 3 and 6). This treatment was without significant effect in the cortical nucleus of the amygdala (Figure 6).

\section{DISCUSSION}

The main result of these studies was a regional specificity of the effect of treatment with estradiol, DHEA, tamoxifen, or raloxifene on $5-\mathrm{HT}_{2 \mathrm{~A}}$ receptor density and mRNA levels. Our results showed that hormonal withdrawal by ovariectomy decreased $5-\mathrm{HT}_{2 \mathrm{~A}}$ receptor density and mRNA levels in rat forebrain, particularly in the cingulate and frontal cortices, as well as the striatum and nucleus accumbens; regions that play a pivotal role in cognition, emotion, neuroendocrine, and motor control (Fink et al. 1998). More specifically, we have subdivided the cortex in its cingulate, frontal and pari- 


\section{In situ Hybridization of the $5-\mathrm{HT}_{2 \mathrm{~A}}$ receptor DHEA treatment}

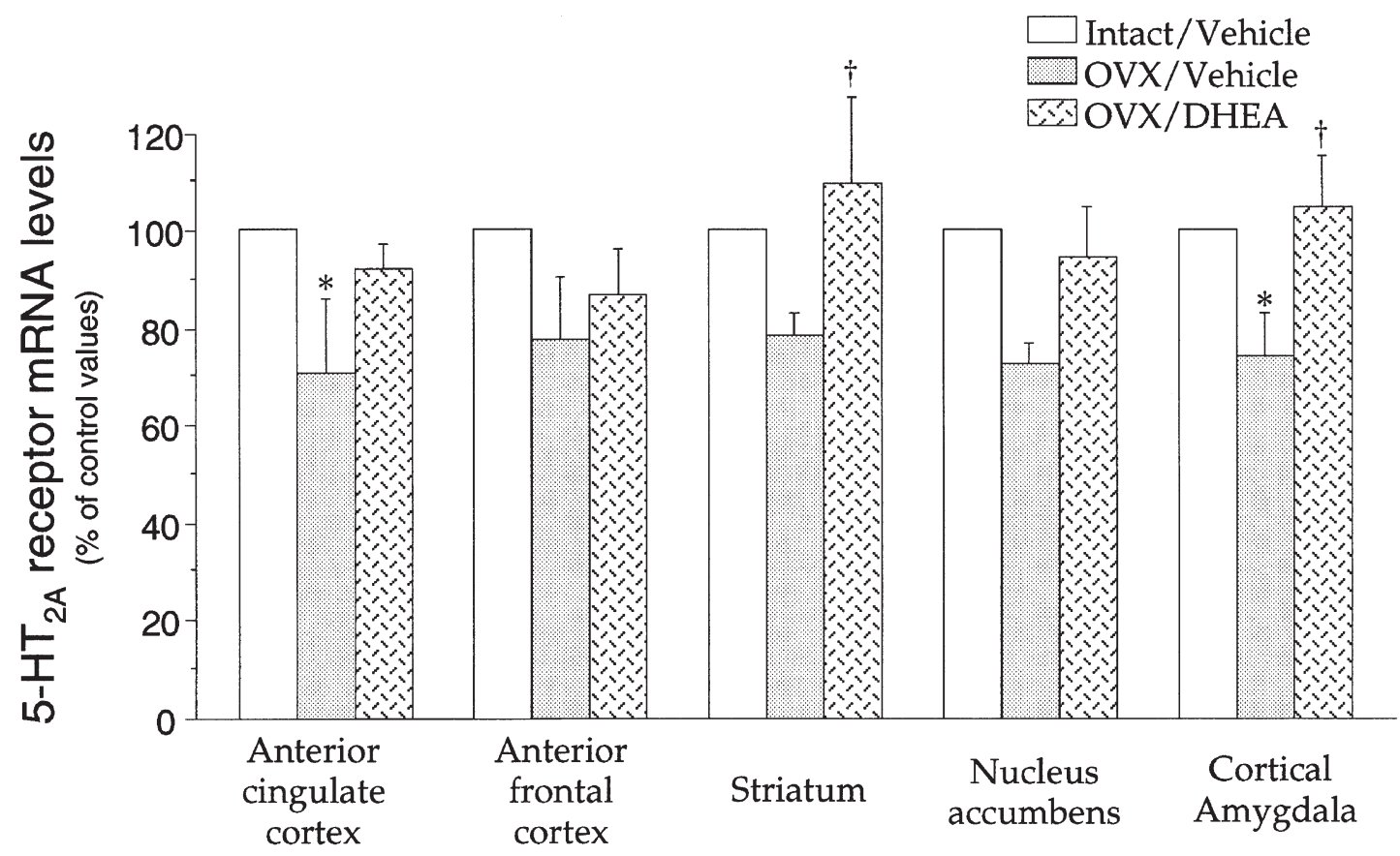

Figure 5. In situ hybridization of $5-\mathrm{HT}_{2 \mathrm{~A}}$ receptors in brain of intact rats as well as ovariectomized rats (two weeks) receiving vehicle (once daily, s.c.) or a replacement therapy with DHEA (30 mg, once daily, topical application) for two weeks. Results are expressed as percent of control values \pm S.E.M. of four rats. Control values (Intact/Vehicle) in relative optical density were 0.247 in anterior cingulate cortex, 0.212 in anterior frontal cortex, 0.072 in striatum, 0.120 in nucleus accumbens, and 0.309 in the cortical nucleus of the amygdala. ${ }^{*} p<.05$ vs. Intact/Vehicle; ${ }^{+} p<.05 \mathrm{OVX} /$ Vehicle.

etal regions; with measures made in their anterior and posterior regions as well as in layers $2,4,5$, and 6 . The hormonal effects were seen in all the cortical layers and were in the anterior but not in the posterior region of the cortical areas assayed. In general, the hormonal effects were more important in the cingulate compared to the frontal cortex, whereas no effect was observed in the parietal cortex.

Chronic exposure to estradiol treatment increased $5-\mathrm{HT}_{2 \mathrm{~A}}$ receptor density and mRNA levels in anterior cingulate and frontal cortices, as well as the striatum and the nucleus accumbens. The other brain regions assayed were not affected by the estradiol treatment. An acute estradiol treatment was previously shown to decrease $5-\mathrm{HT}_{2 \mathrm{~A}}$ receptor mRNA in the medial septum and in the diagonal band of Broca and inversely, to increase in the dorsal raphe nucleus, whereas no effect was observed in the other brain regions assayed (Sumner and Fink 1993). The 5-HT $2 \mathrm{~A}$ receptor mRNA differences between the present results and those of Sumner and Fink are likely due to the chronic versus the acute mode of administration of estradiol.

Our previous binding studies (Cyr et al. 1998) using $\left[{ }^{3} \mathrm{H}\right]$ ketanserin showed that ovariectomy decreased $5-\mathrm{HT}_{2 \mathrm{~A}}$ receptor density compared to intact rat values in the dorsal raphe and brain regions of 5-HT projections such as striatum, nucleus accumbens, and frontal cortex, which is corrected by an estradiol treatment. The effect of estradiol to increase $5-\mathrm{HT}_{2 \mathrm{~A}}$ receptors specific binding of ovariectomized rats was also previously observed using the ligands $\left[{ }^{3} \mathrm{H}\right]-\mathrm{RP} 62203$ (Fink and Sumner 1996), $\left[{ }^{3} \mathrm{H}\right]$ ketanserin (Sumner and Fink 1995) and $\left[{ }^{3} \mathrm{H}\right]$ spiperone (Biegon et al. 1983). The present data confirm these results and these changes were paralleled by a similar pattern of changes of $5-\mathrm{HT}_{2 \mathrm{~A}}$ receptor mRNA levels. This suggests a causal relationship supporting a genomic mechanism of action of estradiol on this receptor.

DHEA treatment increased in the striatum and in the cortical nucleus of the amygdala $5-\mathrm{HT}_{2 \mathrm{~A}}$ receptor mRNA levels, whereas a tendency to increase was observed in the cingulate cortex and the nucleus accumbens of ovariectomized rats, and no effect was observed in the other brain regions. Thus, DHEA treatment had a similar effect, but to a smaller extent than the estradiol treatment. DHEA may be modulating $5-\mathrm{HT}_{2 \mathrm{~A}}$ receptors by itself or by transformation into estradiol or testosterone. Dihydrotestosterone treatment, an androgen that cannot be transformed into estradiol, was previously shown to leave unchanged $5-\mathrm{HT}_{2 \mathrm{~A}}$ receptor levels in 


\section{In situ Hybridization of the $5-\mathrm{HT}_{2 \mathrm{~A}}$ receptor} Tamoxifen or Raloxifene treatments $\square$ Intact/Vehicle OVX/Vehicle
EOVX/Tamoxifen
EDOVX/Raloxifene

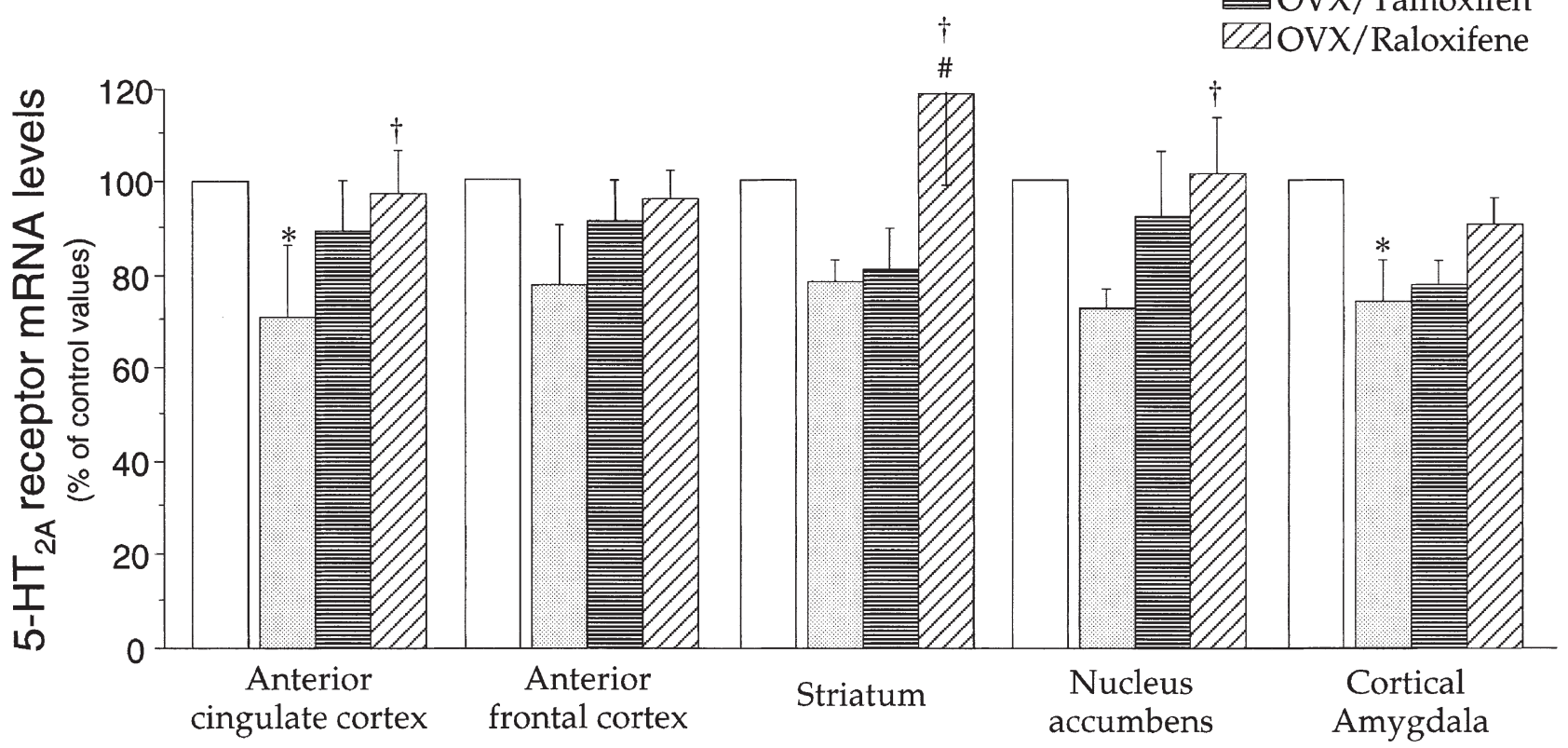

Figure 6. In situ hybridization of $5-\mathrm{HT}_{2 \mathrm{~A}}$ receptors in brain of intact rats as well as ovariectomized rats (two weeks) receiving vehicle (once daily, s.c.) or a replacement therapy with tamoxifen $(250 \mu \mathrm{g})$ or raloxifene $(250 \mu \mathrm{g})$ for two weeks. Results are expressed as percent of control values \pm S.E.M. of four rats. Control values (Intact/Vehicle) in relative optical density were 0.247 in anterior cingulate cortex, 0.212 in anterior frontal cortex, 0.072 in striatum, 0.120 in nucleus accumbens, and 0.309 in the cortical nucleus of the amygdala. ${ }^{*} p<.05$ vs. Intact/Vehicle; ${ }^{\dagger} p<.05 \mathrm{vs.} \mathrm{OVX/Vehicle;}{ }^{\ddagger} p<.05 \mathrm{vs}$. OVX/Estradiol; \# $p<.05$ vs. OVX/Tamoxifen.

male rats (Sumner and Fink 1998), thus, suggesting that our results with DHEA are likely because of its estrogenic rather than androgenic activity.

Tamoxifen and raloxifene have agonist/antagonist estrogenic activity in periphery. For example, tamoxifen is an ER antagonist in breast tissue but an ER agonist in bone and uterine tissues. Raloxifene is also an ER antagonist in breast tissue but by contrast, it exerts agonistic activity in bone but low or none in uterine tissue (Grese and Dodge 1998). The present experiments confirmed the estrogenic agonist activity of tamoxifen and the weak effect of raloxifene on uterine weight. However, raloxifene treatment had a higher estrogenic-like effect on $5-\mathrm{HT}_{2 \mathrm{~A}}$ receptor density and mRNA levels in cortical regions, striatum, and nucleus accumbens than tamoxifen. This suggests that raloxifene, more than tamoxifen, acts as an estrogen agonist in the brain; this is the first such observation.

Ovariectomy, by decreasing $5-\mathrm{HT}_{2 \mathrm{~A}}$ receptor density and mRNA levels in the cortical areas would decrease the propensity of pyramidal cells to fire in response to a $5-\mathrm{HT}$ stimulus. Indeed, the net effect of $5-\mathrm{HT}_{2 \mathrm{~A}}$ receptor activation in this region appears to facilitate neuronal firing (Marek and Aghajanian 1998). This is in agree- ment with hypoactivity of frontal cortex in depression (Klaiber et al. 1979). Moreover, dopaminergic striatal hyperactivity and hypoactivity in the frontal cortex are a current hypothesis in schizophrenia (Willner 1997). Serotonin is suggested to inhibit dopamine function via $5-\mathrm{HT}_{2 \mathrm{~A}}$ receptors (Kapur and Remington 1996). Hence, ovariectomy by decreasing $5-\mathrm{HT}_{2 \mathrm{~A}}$ as well as D1 and D2 receptors (Bosse and Di Paolo 1996) may lead to hypoactivity in the cortex. Thus, DHEA and raloxifene by increasing $5-\mathrm{HT}_{2 \mathrm{~A}}$ receptor density and expression activating cortical activity, could potentially be beneficial such as is observed with estradiol in schizophrenia and depression (Fink et al. 1998; Halbreich 1997).

The estrogenic effect at the genomic level of $5-\mathrm{HT}_{2 \mathrm{~A}}$ receptor could be by the ER. Hence, we sought the presence of an estrogen responsive element in the rat $5-\mathrm{HT}_{2 \mathrm{~A}}$ receptor gene promoter. No correspondence was found between the palindromic sequence GGTCAnnnTGACC of the estrogen responsive element (Truss and Beato 1993) and the complete sequence of the $5-\mathrm{HT}_{2 \mathrm{~A}}$ receptor promoter (Du et al. 1994). However, non-hormone response element containing genes, such as the AP1 response element (Paech et al. 1997), can also respond to the ER ligand (Katzenellenbogen et al. 1996) and are 
present in the 5- $\mathrm{HT}_{2 \mathrm{~A}}$ promoter (Fink et al. 1998). Further investigation with gel shift and DNA footprinting assays are required to clearly investigate this issue.

Nevertheless, it is interesting to compare the distribution of the $5-\mathrm{HT}_{2 \mathrm{~A}}$ receptor mRNA with ER $\alpha$ and $\mathrm{ER} \beta$ subtypes. Note that the distribution found with $\left[{ }^{3} \mathrm{H}\right]$ ketanserin binding and the 5- $\mathrm{HT}_{2 \mathrm{~A}}$ receptor cRNA specific probe by in situ hybridization were similar to a previous report using $\left[{ }^{3} \mathrm{H}\right]$ ketanserin and oligonucleotides (Mengod et al. 1990). Strongest hybridization signal of the $5-\mathrm{HT}_{2 \mathrm{~A}}$ receptor cRNA probe was found in cortical regions of the brain such as the frontal cortex that is the region where a strong estrogenic effect was observed. Little hybridization signal from the specific cRNA probe of the ER $\beta$ but no ER $\alpha$ subtype was found in the frontal cortex (Laflamme et al. 1998). The $\beta$ form of the ER is generally less abundant and highly localized within the limbic system including the nucleus accumbens where an estrogenic effect was also observed and no ER $\alpha$ mRNA was found. Thus, the comparison of our results with those of Laflamme et al. (1998) suggests that the estrogenic effect on $5-\mathrm{HT}_{2 \mathrm{~A}}$ receptors would be mediated by the ER $\beta$, rather than $\alpha$, the mRNA for which is present in the cortical regions as well as in the nucleus accumbens of the rat brain. No expression of the receptor $\alpha$ and $\beta$ was found in the striatum. Hence, unless there is a third type of ER, the estrogenic effect reported here and in previous studies (Cyr et al. 1998; Fink and Sumner 1996; Sumner and Fink 1993, 1998) on striatal $5-\mathrm{HT}_{2 \mathrm{~A}}$ receptors would depend on a non-genomic mechanism, or, alternatively, on inputs from other regions that do contain ERs. An effect of estradiol on membrane fluidity is also possible since the effect of one injection of estradiol on 5- $\mathrm{HT}_{2 \mathrm{~A}}$ receptor was previously reported (Fink and Sumner 1996) and changes in membrane fluidity can alter $\left[{ }^{3} \mathrm{H}\right] 5-\mathrm{HT}$ binding (Heron et al. 1980).

In conclusion, the decrease of brain $5-\mathrm{HT}_{2 \mathrm{~A}}$ receptor after ovariectomy could bring a predisposition factor for schizophrenia and depression in women around the age of menopause. An estradiol treatment therapy, as well as DHEA and SERM treatment, may protect against these predispositions. The mechanism of this protective estrogenic effect may be through the ER $\beta$ rather than $\alpha$, which will, in turn, activate expression of $5-\mathrm{HT}_{2 \mathrm{~A}}$ receptors at the genomic level. The net effect would be an activation of cortical activity.

\section{ACKNOWLEDGMENTS}

The authors are greatly indebted to Dr. Fernand Labrie for the generous gift of perfused rat brain slices from animals of the protocol URMAr 50-97 and raloxifene which was synthesized in the medicinal chemistry division of his laboratory. This research was supported by a grant from the Medical Research Council (MRC) of Canada to T.D.P.; M.C. and M.L. are holders of a MRC of Canada studentship.

\section{REFERENCES}

Bethea CL, Pecins-Thompson M, Schutzer WE, Gundlah C, Lu ZN (1998): Ovarian steroids and serotonin neural function. Mol Neurobiol 18:87-123

Biegon A, Reches A, Snyder L, McEwen BS (1983): Serotoninergic and noradrenergic receptors in the rat brain: Modulation by chronic exposure to ovarian hormones. Life Sci 32:2015-2021

Bosse R, Di Paolo T (1996): The modulation of brain dopamine and $\mathrm{GABA}_{\mathrm{A}}$ receptors by estradiol: A clue for CNS changes occurring at menopause. Cell Mol Neurobiol 16:199-212

Charney DS (1998): Monoamine dysfunction and the pathophysiology and treatment of depression. J Clin Psychiatry 59:11-14

Cyr M, Bosse R, Di Paolo T (1998): Gonadal hormones modulate 5-hydroxytryptamine2A receptors: Emphasis on the rat frontal cortex. Neuroscience 83:829-836

Cyr M, Ghribi O, Di Paolo T (2000): Ovariectomy and gonadal modulation of glutamate levels and glutamate receptors of the NMDA and AMPA subtypes. J. Neuroendocrinol (in press).

Di Paolo T (1994): Modulation of brain dopamine transmission by sex steroids. Rev Neurosci 5:27-41

Du YL, Wilcox BD, Teitler M, Jeffrey JJ (1994): Isolation and characterization of the rat 5-hydroxytryptamine type 2 receptor promoter: Constitutive and inducible activity in myometrial smooth muscle cells. Mol Pharmacol 45:1125-1131

Fink G, Sumner BE (1996): Oestrogen and mental state. Nature 383:306

Fink G, Sumner BE, McQueen JK, Wilson H, Rosie R (1998): Sex steroid control of mood, mental state and memory. Clin Exp Pharmacol Physiol 25:764-775

Grese TA, Dodge JA (1998): Selective estrogen receptor modulators (SERMs). Curr Pharm Des 4:71-92

Halbreich U (1997): Role of estrogen in postmenopausal depression. Neurology 48:S16-S19

Heron DS, Shinitzky M, Hershkowitz M, Samuel D (1980): Lipid fluidity markedly modulates the binding of serotonin to mouse brain membranes. Proc Natl Acad Sci USA 77:7463-7467

Kapur S, Remington G (1996): Serotonin-dopamine interaction and its relevance to schizophrenia. Am J Psychiatry 153:466-476

Katzenellenbogen JA, O'Malley BW, Katzenellenbogen BS (1996): Tripartite steroid hormone receptor pharmacology: Interaction with multiple effector sites as a basis for the cell- and promoter-specific action of these hormones. Mol Endocrinol 10:119-131

Klaiber EL, Broverman DM, Vogel W, Kobayashi Y (1979): Estrogen therapy for severe persistent depressions in women. Arch Gen Psychiatry 36:550-554

Labrie C, Flamand M, Belanger A, Labrie F (1996): High bioavailability of dehydroepiandrosterone administered percutaneously in the rat. J Endocrinol 150(Suppl):S107S118

Laflamme N, Nappi RE, Drolet G, Labrie C, Rivest S (1998): 
Expression and neuropeptidergic characterization of estrogen receptors (ERalpha and ERbeta) throughout the rat brain: anatomical evidence of distinct roles of each subtype. J Neurobiol 36:357-378

Lieberman JA, Mailman RB, Duncan G, Sikich L, Chakos M, Nichols DE, Kraus JE (1998): Serotonergic basis of antipsychotic drug effects in schizophrenia. Biol Psychiatry 44:1099-1117

Marek GJ, Aghajanian GK (1998): The electrophysiology of prefrontal serotonin systems: Therapeutic implications for mood and psychosis. Biol Psychiatry 44:1118-1127

Martel C, Labrie C, Belanger A, Gauthier S, Merand Y, Li X, Provencher L, Candas B, Labrie F (1998): Comparison of the effects of the new orally active antiestrogen EM-800 with ICI 182780 and toremifene on estrogen-sensitive parameters in the ovariectomized mouse. Endocrinology 139:2486-2492

Mengod G, Pompeiano M, Martinez-Mir MI, Palacios JM (1990): Localization of the mRNA for the 5-HT2 receptor by in situ hybridization histochemistry. Correlation with the distribution of receptor sites. Brain Res 524:139-143

Paech K, Webb P, Kuiper GGJM, Nilsson S, Gustafsson J-A, Kushner PJ, Scanlan TS (1997): Differential ligand activation of estrogen receptors ER $\alpha$ and ER $\beta$ at AP1 sites. Science 277:1508-1510

Paige LA, Christensen DJ, Gron H, Norris JD, Gottlin EB, Padilla KM, Chang CY, Ballas LM, Hamilton PT, McDonnell DP, Fowlkes DM (1999): Estrogen receptor
(ER) modulators each induce distinct conformational changes in ER alpha and ER beta. Proc Natl Acad Sci USA 96:3999-4004

Paxinos G, Watson C (1998): The rat brain in stereotaxic coordinates. 4th ed. New York, Academic Press

Pritchett DB, Bach AW, Wozny M, Taleb O, Dal Toso R, Shih JC, Seeburg PH (1988): Structure and functional expression of cloned rat serotonin 5HT-2 receptor. Embo J 7:4135-4140

Sumner BEH, Fink G (1993): Effects of acute estradiol on 5-hydroxytryptamine and dopamine receptor subtype mRNA expression in female rat brain. Molec Cell Neurosci 4:83-92

Sumner BEH, Fink G (1995): Estrogen increases the density of 5-hydroxytryptamine(2A) receptors in cerebral cortex and nucleus accumbens in the female rat. J Steroid Biochem Mol Biol 54:15-20

Sumner BEH, Fink G (1998): Testosterone as well as estrogen increases serotonin $2 \mathrm{~A}$ receptor $\mathrm{mRNA}$ and binding site densities in the male rat brain. Brain Res Mol Brain Res 59:205-214

Truss M, Beato M (1993): Steroid hormone receptors: Interaction with deoxyribonucleic acid and transcription factors. Endocr Rev 14:459-479

Willner P (1997): The dopamine hypothesis of schizophrenia: Current status, future prospects. Int Clin Psychopharmacol 12:297-308

Zifa E, Fillion G (1992): 5-Hydroxytryptamine receptors. Pharmacol Rev 44:401-458 